\title{
Chlorophyll fluorescence and gas exchange measurements in field research: an ecological case study
}

\author{
S.F. BUCHER ${ }^{*, * *+}$, M. BERNHARDT-RÖMERMANN*, and C. RÖMERMANN ${ }^{*}{ }^{* *}$ \\ Institute of Ecology and Evolution with Herbarium Haussknecht and Botanical Garden, Friedrich Schiller University \\ Jena, D-07743 Jena, Germany* \\ German Centre for Integrative Biodiversity Research (iDiv) Halle-Jena-Leipzig, D-04103 Leipzig, Germany**
}

\begin{abstract}
We tested whether cheap and quick chlorophyll (Chl) fluorescence can be used in ecophysiological field studies as proxies for gas-exchange measurements. We measured net photosynthetic rate at saturating irradiance and ambient atmospheric $\mathrm{CO}_{2}$ concentrations $\left(P_{\text {Nsat }}\right)$, maximum carboxylation rate $\left(\mathrm{V}_{\mathrm{cmax}}\right)$, maximum quantum yield of PSII ( $\left.\mathrm{F}_{\mathrm{v}} / \mathrm{F}_{\mathrm{m}}\right)$, the performance index $\left(\mathrm{PI}_{\mathrm{abs}}\right)$, leaf nitrogen $\left(\mathrm{N}_{\text {area }}\right)$, and carbon isotope discrimination $\left(\Delta^{13} \mathrm{C}\right)$ within four herbaceous species along two elevational gradients. We analysed the relationship between $\mathrm{Chl}$ fluorescence and gas-exchange parameters and their link to indirect assessment of plant performance via ecophysiological traits. $\mathrm{F}_{\mathrm{v}} / \mathrm{F}_{\mathrm{m}}$ showed no relationship to $P_{\text {Nsat }}$ and only weak relationships to $\mathrm{V}_{\text {cmax }}$. $\mathrm{PI}_{\text {abs }}$ was positively related to $P_{\text {Nsat }}$ and $\mathrm{V}_{\text {cmax }}$. $\mathrm{PI}_{\text {abs }}, P_{\text {Nsat }}$, and $\mathrm{V}_{\text {cmax }}$ were positively associated with $\mathrm{N}_{\text {area }}$ and negatively to $\Delta^{13} \mathrm{C}$, whereas $\mathrm{F}_{\mathrm{v}} / \mathrm{F}_{\mathrm{m}}$ showed no relationship to $\mathrm{N}_{\text {area }}$ and a positive to $\Delta^{13} \mathrm{C}$. Thus, $\mathrm{PI}_{\mathrm{abs}}$ might be suitable to characterize the photosynthetic activity when aiming on large numbers of samples.
\end{abstract}

Additional key words: Aposeris foetida, carbon isotope discrimination, Knautia dipsacifolia, leaf nitrogen, Mercurialis perennis, Trifolium pratense.

\section{Introduction}

Photosynthesis is the main process in the physiology of all plant species and facilitates life on the Earth as we know it today. Light quanta absorbed by Chl can undergo three different fates: they can be used photochemically driving photosynthesis, be dissipated as heat or they can be reemitted as light, the so called $\mathrm{Chl} a$ fluorescence (Maxwell and Johnson 2000). Photosynthetic activities of plants are mostly quantified via gas-exchange measurements, where the quantity of $\mathrm{CO}_{2}$ absorbed by leaf tissue per unit area (or mass) and time is measured (Von Caemmerer and Farquhar 1981, Küppers et al. 1987). However, Chl a fluorescence is increasingly used in ecology to assess the vitality and performance of plants, since this nondestructive method is fast, cost effective, and requires a minimum of expertise in contrast to the traditional gas-exchange measurements (Schreiber et al. 1995, Clark et al. 2000, Dias and Brüggemann 2010). The question is, whether Chl $a$ fluorescence is linked to gasexchange measurements under field conditions and whether we can use this faster and easier method to deduce ecophysiologically relevant parameters. We explicitly do not focus on enhancing the ecophysiological understanding of the relation between Chl $a$ fluorescence and gas-exchange measurements, but on the applicability of

Received 13 April 2017, accepted 18 August 2017, published as online-first 12 April 2018.

${ }^{+}$Corresponding author; phone: +49 36419 49986, e-mail: Solveig.franziska.bucher@uni-jena.de

Abbreviations: $\mathrm{Chl}$ - chlorophyll; $\mathrm{F}_{\mathrm{v}} / \mathrm{F}_{\mathrm{m}}$ - maximum quantum yield of PSII; $\mathrm{N}_{\text {area }}$ - area based leaf nitrogen content; PIabs - absorption based performance index; $P$ Nsat - net photosynthetic rate at saturating irradiance and ambient atmospheric $\mathrm{CO}_{2}$ concentrations; $\mathrm{V}_{\mathrm{cmax}}$ - maximum carboxylation rate; $\Delta^{13} \mathrm{C}$ - carbon isotope discrimination.

Acknowledgements: The authors would like to thank the members of the Institute of Botany at the University of Regensburg and the Institute of Systematic Botany at the FSU Jena for practical assistance and valuable discussions. We are grateful for the assistance and analysation of nitrogen at the Technical University of Munich, Grassland group, and financial support for this analysis from the German Centre for Integrative Biodiversity Research (iDiv) Halle-Jena-Leipzig. We would also like to thank Anna Geiger and Johanna Otto for practical assistance in the field and Prof. Dr. Manfred Küppers as well as Dr. Jens Kattge for valuable discussions and suggestions. We are grateful about the Eliteförderung des Landes Bayern for provision of a scholarship (granted to S.F. Bucher) and the Universities of Regensburg and Jena. The work of C. Römermann and M. Bernhardt-Römermann was partly funded by the DFG (German Research Foundation, RO 3842/3-1 and BE 4143/2_1). We also acknowledge support from the Bavarian State Forest Enterprise and the district government of upper Bavaria. 
Chl $a$ fluorescence parameters in extensive ecological and ecophysiological field studies as proxies for the cost and time intensive gas-exchange measurements.

The Chl $a$ fluorescence accounts for $1-2 \%$ of the total light absorbed and holds important information on the performance of plants (Maxwell and Johnson 2000, Kalaji et al. 2014, 2017a,b). Chl a fluorescence of a leaf, which is triggered by a light pulse after dark adaption, rises very fast from a dark-adapted ground fluorescence value $\left(\mathrm{F}_{0}\right)$ to a maximum fluorescence value $\left(F_{m}\right)$. It subsequently decreases to a steady-state value due to an increase of electron transport away from PSII and an increased efficiency of energy conversion into heat. This general pattern was described as the Kautsky effect (Kautsky and Franck 1943). Continuous excitation fluorimeters detect this transient light-induced O-J-I-P fluorescence (named after the local maxima of the response curve), where the intensity of Chl $a$ fluorescence is displayed against time which is solicited by a saturating light pulse (Strasser et al. 2000, Lazár 2006). This transient has been referred to as the barcode for photosynthesis (Tyystjärvi et al. 1999) and further parameters can be deduced thereof such as the two parameters, which are often used to answer ecological questions: the maximum quantum yield of PSII $\left(\mathrm{F}_{\mathrm{v}} / \mathrm{F}_{\mathrm{m}}\right)$ and the absorption-based performance index $\left(\mathrm{PI}_{\mathrm{abs}}\right) . \mathrm{F}_{\mathrm{v}} / \mathrm{F}_{\mathrm{m}}$, where the variable fluorescence $F_{v}$ is defined as $F_{m}-F_{0}$, is an indicator for the potential activity of PSII of a leaf, whereas $\mathrm{PI}_{\mathrm{abs}}$ is a measure of photosynthetic performance. $\mathrm{PI}_{\mathrm{abs}}$ comprises information on the density of fully active reaction centres, the probability that an absorbed photon will be trapped by a reaction centre and the efficiency of electron movement by a trapped exciton beyond the primary acceptor quinone $\mathrm{Q}_{\mathrm{A}}$ (Kitajima and Butler 1975, Strasser et al. 1999, Clark et al. 2000, Strasser et al. 2000, Živčák et al. 2008). $\mathrm{PI}_{\text {abs }}$ therefore includes the density of fully active radiation centres, the efficiency of electron movement to the electron transport chain and the probability that an absorbed photon will be trapped by the reaction centres. Thus, $\mathrm{PI}_{\mathrm{abs}}$ encompasses the functionality of PSI and PSII (Strasser and Srivastava 1995, Strasser et al. 2000). Chl $a$ fluorescence has been used to answer various ecological questions being related to e.g. ozone sensitivity (Clark et al. 2000), the onset of autumn senescence (Holland et al. 2014), water stress (Živčák et al. 2008), the determination of frost acclimatisation and effects (Neuner et al. 1999, Pflug and Brüggemann 2012) or the effect of temperature on plant vitality and heat stress tolerance under laboratory conditions (Maxwell and Johnson 2000, Neuner and Pramsohler 2006, Sharma et al. 2015).

Maximum light-saturated photosynthetic rates, $P_{\text {Nsat }}$, are photosynthetic rates at saturating light conditions under current atmospheric $\mathrm{CO}_{2}$ concentration (400 ppm) and optimal humidity (around 60\%). Changes in maximum photosynthetic rates are not reflecting the intrinsic photosynthetic capacity but rather the $\mathrm{CO}_{2}$ availability at the sites of carboxylation, which depends on the stomatal characteristics and their response to environmental cues (Grassi et al. 2005). Thus, most studies rather use the maximum carboxylation rate, $\mathrm{V}_{\mathrm{cmax}}$, or the maximum rate of electron transport, $\mathrm{J}_{\max }$, as more appropriate parameters to characterize leaf photosynthesis. $\mathrm{V}_{\mathrm{cmax}}$ is assessed via time intensive $P_{\mathrm{N}}-C_{\mathrm{i}}$ curves, where photosynthetic rates, $P_{\mathrm{N}}$, are measured under varying intercellular $\mathrm{CO}_{2}$ concentrations, $C_{\mathrm{i}}$ (Farquhar et al. 1980, Grassi et al. 2005). However, following Wilson et al. (2000) and De Kauwe et al. (2016), $\mathrm{V}_{\mathrm{cmax}}$ can also be calculated from the simpler $P_{\text {Nsat }}$ measurements via the so called 'one-point method'.

Another way to determine the plant performance, which is gaining more and more attention in ecological field studies, are indirect measurements via ecophysiological plant traits (Violle et al. 2007, de Bello et al. 2010, Pérez-Harguindeguy et al. 2013, Bucher et al. 2016, Römermann et al. 2016). Area-based leaf nitrogen content $\left(\mathrm{N}_{\text {area }}\right)$ is a good proxy for plant photosynthetic capacity, since most of the nitrogen is located in proteins of the Calvin cycle (mainly Rubisco) and thylakoids, which is proportional to Chl content (Evans 1989, Bond et al. 1999) and offers an insight to the chemical component of photosynthesis. We expect that besides the well-defined relationship between gas-exchange parameters and $\mathrm{N}_{\text {area }}$ (Evans 1989, Bond et al. 1999), at least $\mathrm{PI}_{\mathrm{abs}}$ should be positively related to $\mathrm{N}_{\text {area }}$ since it is a measure of photosynthetic performance. Carbon isotope discrimination $\left(\Delta^{13} \mathrm{C}\right)$ is indicating the gradient between $C_{\mathrm{i}}$ and external $\mathrm{CO}_{2}$ concentration $\left(C_{\mathrm{a}}\right)$ and is thus a proxy for intrinsic water-use efficiency since Rubisco is discriminating against ${ }^{13} \mathrm{C}$ and favours ${ }^{12} \mathrm{C}$ when $\mathrm{CO}_{2}$ is sufficiently available. $\Delta^{13} \mathrm{C}$ is high if $C_{\mathrm{i}} / C_{\mathrm{a}}$ is high, which is the case if either the stomata are open or there is a low demand of $\mathrm{CO}_{2}$ due to reduced photosynthetic rates (Farquhar et al. 1989, Pérez-Harguindeguy et al. 2013). Thus, we hypothesise that besides gas-exchange parameters, $\mathrm{PI}_{\mathrm{abs}}$ should be positively related to $\mathrm{N}_{\text {area }}$.

The main aim our case study was to test if Chl $a$ fluorescence measurements are suitable in extensive measurements in ecological field studies and how much information on ecophysiological processes can be derived thereof to obtain a better ecological understanding of these different methods applied in the field. More precisely, we asked the following questions:

Are Chl $a$ fluorescence parameters related to gasexchange measurements under field conditions?

Are Chl $a$ fluorescence and gas-exchange parameters related to indirect measurements of plant performance via ecophysiological traits? 


\section{Materials and methods}

All measurements were conducted in the Northern Limestone Alps near Garmisch-Partenkirchen along two south facing elevational gradients ("Kramer" and "Kreuzeck") ranging from 700 to 1,700 and from 800 to $1,700 \mathrm{~m}$ a.s.1., respectively. We chose to conduct our research along the elevational gradients since we could find plants adapted to a wide range of abiotic conditions at a relatively small spatial scale. Four herbaceous plant species (all following $\mathrm{C}_{3}$ metabolism) occurring along a wide elevational range were selected for this analysis, namely Aposeris foetida (L.) Less, Knautia dipsacifolia Kreutzer, Mercurialis perennis L., and Trifolium pratense L. Samples were collected every $100-\mathrm{m}$ increase in elevation at altogether 22 sites as far as individuals were abundant. Five mature individuals at full flowering (May for A. foetida and M. perennis and August for K. dipsacifolia and $T$. pratense) were selected per site and species, leading to an overall dataset of more than 100 measurements per species. Chl $a$ fluorescence as well as gasexchange measurements were recorded and ecophysiological traits of the plants were measured following standardized protocols (Pérez-Harguindeguy et al. 2013). Fluorescence and gas-exchange measurements were not performed between 12:00 $\mathrm{h}$ and 14:00 $\mathrm{h}$ in order to avoid midday depressions (Demmig-Adams et al. 1989, Lichtenthaler et al. 2005, Desotgiu et al. 2013).

Chl $\boldsymbol{a}$ fluorescence: For each individual, two leaves (one being the same as used for gas-exchange measurements) were selected to measure $\mathrm{Chl} a$ fluorescence transients on the adaxial side [since $\mathrm{Chl} a$ fluorescence varies with $\mathrm{Chl}$ concentration, which is higher in palisade parenchyma (Lichtenthaler et al. 1986)]. We used a plant efficiency analyser, a portable continuous excitation time resolved Chl fluorimeter [Pocket PEA, Hansatech Inst., UK; Strasser and Srivastava (1995)]. For an overview on different $\mathrm{Chl} a$ fluorescence techniques and the parameters which can be derived thereof [see e.g. Maxwell and Johnson (2000), Kalaji et al. (2014) or Kalaji et al. (2017a)]. Prior to measurements, leaves were dark-adapted for 40 min using black leaf clips. Leaf clips were covered with other leaves to prevent an increase in minimum fluorescence, $\mathrm{F}_{0}$, through overheating. For $A$. foetida, $K$. dipsacifolia, and $M$. perennis, veins were avoided for measurements since they adulterate fluorescence measurements (Lichtenthaler et al. 2005, Lazár 2006, Giorio 2011). With continuous excitation fluorimeters, the transient light-induced O-J-I-P fluorescence was recorded at $10-\mu$ s intervals and the maximum PSII quantum yield, $\mathrm{F}_{\mathrm{v}} / \mathrm{F}_{\mathrm{m}}$, and the $\mathrm{Chl} a$ fluorescence performance index $\left(\mathrm{PI}_{\mathrm{abs}}\right)$ were calculated thereof (Strasser and Srivastava 1995, Clark et al. 2000). The maximum light intensity was 3,500 $\mu$ mol(photon) $\mathrm{mm}^{-2} \mathrm{~s}^{-1}$ which was applied for $1 \mathrm{~s}$ with a light emitting diode at a $625 \mathrm{~nm}$ wavelength. $\mathrm{F}_{0}$ is defined as the fluorescence after $50 \mu$ s of light emission
(Sušila et al. 2004).

The maximum quantum yield of the PSII was calculated as:

$$
\mathrm{F}_{\mathrm{v}} / \mathrm{F}_{\mathrm{m}}=\frac{\left(\mathrm{F}_{\mathrm{m}}-\mathrm{F}_{0}\right)}{\mathrm{F}_{\mathrm{m}}}
$$

$F_{v}$ defines the variable fluorescence, which is the difference between the maximum fluorescence $F_{m}$ and the minimum fluorescence $\mathrm{F}_{0}$ of dark-adapted leaves. This fluorescence is mainly emitted by PSII (Kitajima and Butler 1975, Maxwell and Johnson 2000, Sušila et al. 2004). Theoretically, the maximum PSII quantum yield would be 1 ( 1 photon absorbed by PSII leads to a transport of 1 electron). However, most studies report values between 0.70 and 0.85 since energy is dissipated via heat and Chl $a$ fluorescence (Kalaji et al. 2014).

$\mathrm{PI}_{\mathrm{abs}}$ was calculated following the JIP-test which is based on Chl $a$ fluorescence characteristics of the first 2 ms (see Eq. 2; Strasser and Srivastava 1995, Clark et al. 2000). It includes the density of fully active radiation centres, the efficiency of electron movement to the electron transport chain, and the probability that an absorbed photon will be trapped by the reaction centres and thus encompasses the functionality of PSI and PSII (Strasser et al. 2000). It is calculated via the simplified experimental formula:

$$
\mathrm{PI}_{\mathrm{abs}}=\frac{\mathrm{RC}}{\mathrm{ABS}} \times \frac{\mathrm{F}_{\mathrm{v}}}{\mathrm{F}_{0}} \times \frac{1-\mathrm{V}_{\mathrm{j}}}{\mathrm{V}_{\mathrm{j}}}
$$

Here, RC are the active PSII reaction centres, ABS is the light absorbed by antennae and $\mathrm{V}_{\mathrm{j}}$ is the variable fluorescent rise at $2 \mathrm{~ms}$ (Strasser and Srivastava 1995, Clark et al. 2000). $\mathrm{PI}_{\mathrm{abs}}$ reflects thus the efficiency of energy conservation of PSII from absorbed photons to reduce the intermediate electron carriers of the plastid electron transport chain.

$\boldsymbol{P}_{\text {Nsat }}$ measurements and $\mathbf{V}_{\text {cmax }}$ estimates: For each individual, net photosynthetic rate at saturating irradiance and at ambient atmospheric $\mathrm{CO}_{2}$ concentrations $\left(P_{\mathrm{Nsat}}\right)$ was measured using the Li-6400XT (LI-COR Bioscience, Lincoln, Nebraska). Irradiance was kept constant at 2,000 $\mu \mathrm{mol}$ (photon) $\mathrm{m}^{-2} \mathrm{~s}^{-1}$ and $\mathrm{CO}_{2}$ concentration at $400 \mathrm{ppm}$. In summer $2013, K$. dipsacifolia and $T$. pratense were measured at $25^{\circ} \mathrm{C}$ block temperature. In spring 2014, M. perennis and $A$. foetida were measured at $17^{\circ} \mathrm{C}$ block temperature due to technical limitation, which only allows heating/cooling to a certain extent. Plants were adapted to cuvette conditions until constant photosynthetic rates were reached prior measurements.

We calculated $\mathrm{V}_{\text {cmax }}$ from $P_{\mathrm{Nsat}}$ measurements via the 'one-point method' since previous studies found that $P_{\text {Nsat }}$ is limited by Rubisco carboxylation rather than by the regeneration of ribulose-1,5-bisphosphate (RuBP; Rogers and Humphries 2000, Wilson et al. 2000, De Kauwe et al. 
2016). As we did not measure the leaf mitochondrial respiration in the light $\left(\mathrm{R}_{\text {day }}\right)$ using $P_{\mathrm{N}}-C_{\mathrm{i}}$ curves, we assumed that $\mathrm{R}_{\text {day }}$ was $1.5 \%$ of $\mathrm{V}_{\text {cmax }}$ even at differing leaf temperatures due to similar temperature dependencies of $\mathrm{R}_{\text {day }}$ and $\mathrm{V}_{\mathrm{cmax}}$ (Collatz et al. 1991, De Kauwe et al. 2016). $\mathrm{V}_{\mathrm{cmax}}$ was calculated following Collatz et al. (1991) as:

$$
\mathrm{V}_{\mathrm{cmax}}=P_{\mathrm{Nsat}} \times\left(\frac{\mathrm{c}_{\mathrm{i}}+\mathrm{K}_{\mathrm{m}}}{\mathrm{c}_{\mathrm{i}}-\Gamma^{*}}-0.015\right)
$$

Here, $C_{\mathrm{i}}$ is the internal $\mathrm{CO}_{2}$ concentration within the leaf, $\mathrm{K}_{\mathrm{m}}$ is the Michaelis-Menten constant of Rubisco, and $\Gamma^{*}$ [ $\mu \mathrm{mol} \mathrm{mol}^{-1}$ ] is the $\mathrm{CO}_{2}$-compensation point in the absence of mitochondrial respiration. $\mathrm{K}_{\mathrm{m}}$ was calculated following the parametrization made based on in vivo experiments on Nicotiana tabacum L. (Bernacchi et al. 2001) as:

$$
\mathrm{K}_{\mathrm{m}}=\mathrm{K}_{\mathrm{c}}\left(1+\frac{\mathrm{O}_{\mathrm{i}}}{\mathrm{K}_{\mathrm{o}}}\right)
$$

Where $\mathrm{K}_{\mathrm{c}}$ is the Michaelis-Menten constant for the carboxylation and calculated as:

$$
\mathrm{K}_{\mathrm{c}}=404.9 \exp \left(\frac{79,403 \times\left(\mathrm{T}_{\mathrm{k}}-298.15\right)}{298.15 \times \mathrm{R} \times \mathrm{T}_{\mathrm{k}}}\right)
$$

Where $T_{k}$ is the leaf temperature in Kelvin and $\mathrm{R}$ is the universal gas constant $\left(8.314 \mathrm{~J} \mathrm{~mol}^{-1} \mathrm{~K}^{-1}\right)$ and $\mathrm{O}_{\mathrm{i}}$ is the internal concentration of oxygen which is assumed to be $210 \mathrm{mmol} \mathrm{mol}^{-1}$ at sea level, and $\mathrm{K}_{\mathrm{o}}$ is the MichaelisMenten constant for the oxygenase function and calculated as:

$$
\mathrm{K}_{\mathrm{o}}=278.4 \exp \left(\frac{36,380 \times\left(\mathrm{T}_{\mathrm{k}}-298.15\right)}{298.15 \times \mathrm{R} \times \mathrm{T}_{\mathrm{k}}}\right)
$$

The $\mathrm{CO}_{2}$-compensation point in the absence of mitochondrial respiration $\Gamma^{*}$ was calculated as:

$$
\Gamma^{*}=42.75 \exp \left(\frac{37,830 \times\left(\mathrm{T}_{\mathrm{k}}-298.15\right)}{298.15 \times \mathrm{R} \times \mathrm{T}_{\mathrm{k}}}\right)
$$

Ecophysiological traits related to plant performance: To measure $\mathrm{N}_{\text {area }}$ and $\Delta^{13} \mathrm{C}$, the two leaves per individual used for Chl $a$ fluorescence analysis and gas-exchange measurements were collected, dried, weighed, and ground using a ball mill after recording the leaf area. Mass-based leaf nitrogen concentration $\left[\mathrm{mg} \mathrm{g}^{-1}\right.$ ] as well as $\delta^{13} \mathrm{C}[\%$ ] were measured simultaneously with an elemental analyser (NA 1110, Carlo Erba, Milan, Italy). Leaf nitrogen concentration per unit leaf area was calculated by dividing the mass based concentrations by the specific leaf area (SLA), the ratio of fresh leaf area to dry mass, which was measured prior to grounding. Carbon isotope discrimination $\left(\Delta^{13} \mathrm{C}\right)$ was measured and calculated from $\delta^{13} \mathrm{C}$ of the leaves and atmospheric $\delta^{13} \mathrm{C}$ values $\left(\delta^{13} \mathrm{C}_{\text {air }}\right)$ of the station at Hohenpeißenberg at $35 \mathrm{~km}$ distance from our sample location (available at http://www.esrl.noaa.gov/ $\mathrm{gmd} / \mathrm{dv} / \mathrm{data} /$ ) following Farquhar et al. (1989). $\Delta^{13} \mathrm{C}$ was used instead of $\delta^{13} \mathrm{C}$, since $\delta^{13} \mathrm{C}_{\text {air }}$ varied between -9.094\% in February 2013 and $-7.946 \%$ in August 2013. We used $\delta^{13} \mathrm{C}_{\mathrm{air}}$ measured one month before sampling collection assuming that this was the main growth period of the leaves as described in Bucher et al. (2016).

Statistical analysis: In a first analysis, we tested how species differed in parameter values $\left(P_{\text {Nsat }}, V_{\text {cmax }}, \mathrm{F}_{\mathrm{v}} / \mathrm{F}_{\mathrm{m}}\right.$, $\mathrm{PI}_{\text {abs, }} \mathrm{N}_{\text {area }}$, and $\Delta^{13} \mathrm{C}$ ) using an analysis of variance (ANOVA) followed by pairwise comparisons using $t$-test, with a $p$-value adjustment according to Holm. We then tested for relationships between $\mathrm{Chl} a$ fluorescence parameters $\left(\mathrm{F}_{\mathrm{v}} / \mathrm{F}_{\mathrm{m}}, \mathrm{PI}_{\mathrm{abs}}\right)$ and carboxylation rates $\left(P_{\mathrm{Nsat}}\right.$, $\mathrm{V}_{\mathrm{cmax}}$ ) using linear mixed effect models. In these models, $P_{\text {Nsat }}$ and $\mathrm{V}_{\text {cmax }}$ were the dependent variables. Each of the two Chl $a$ fluorescence parameters was included in two separate models together with species as fixed effects allowing two-way interactions; elevation and gradient as well as their interaction were included as random effects to account for spatial autocorrelation.

To analyse each combination of the two Chl $a$ fluorescence parameters $v s$. the two descriptors of carboxylation rates, in total four linear mixed effect models were fitted and simplified via backward selection of the least significant variables until the final minimal adequate model obtained a minimal Akaike information criterion (Crawley 2012). Model requirements and assumptions were fulfilled, as variances were homogeneous and residuals normally distributed.

To extract the relative influence of the fixed compared to the random effects, two $R^{2}$ values were calculated for each model, the $R^{2}$ marginal, which is the $\mathrm{R}^{2}$ value associated with the fixed effects, and the $R^{2}$ conditional, which includes the fixed and the random effect (Nakagawa and Schielzeth 2013).

The same was done for all bivariate relationships of the parameters related to photosynthesis $\left(P_{\mathrm{Nsat}}, \mathrm{V}_{\mathrm{cmax}}, \mathrm{F}_{\mathrm{v}} / \mathrm{F}_{\mathrm{m}}\right.$, $\left.\mathrm{PI}_{\mathrm{abs}}\right)$ and $\mathrm{N}_{\text {area }}$ as well as $\Delta^{13} \mathrm{C}$, respectively.

All analyses were conducted in $R$ version 3.2 .3 ( $R$ Development Core Team 2016), for the analysis of the mixed effect models the packages 'Ime4' (Bates et al. 2015), 'ImerTest' (Kuznetsova et al. 2015) and 'MuMIn' (Bartoń 2016) were used, for graphical display we used 'ggplot2' (Wickham 2009).

\section{Results}

Species-specific differences in parameter values: Gas exchange (Fig. 1A,B), Chl $a$ fluorescence (Fig. $1 C, D$ ), and ecophysiological trait values (Fig. $1 E, F$ ) were highly species-specific. This was especially pronounced in $P_{\text {Nsat }}$ $\left(\mathrm{F}_{3,387}=146.1, p<0.001\right)$ and $\mathrm{V}_{\mathrm{cmax}}$ values $\left(\mathrm{F}_{3,385}=249.3\right.$, $p<0.001)$. All species were significantly different from each other $(M$. perennis $<A$. foetida $<K$. dipsacifolia $<$ $T$. pratense), with the two species measured in the spring (A. foetida and M. perennis) displaying lower values than the two species measured in the summer under higher 


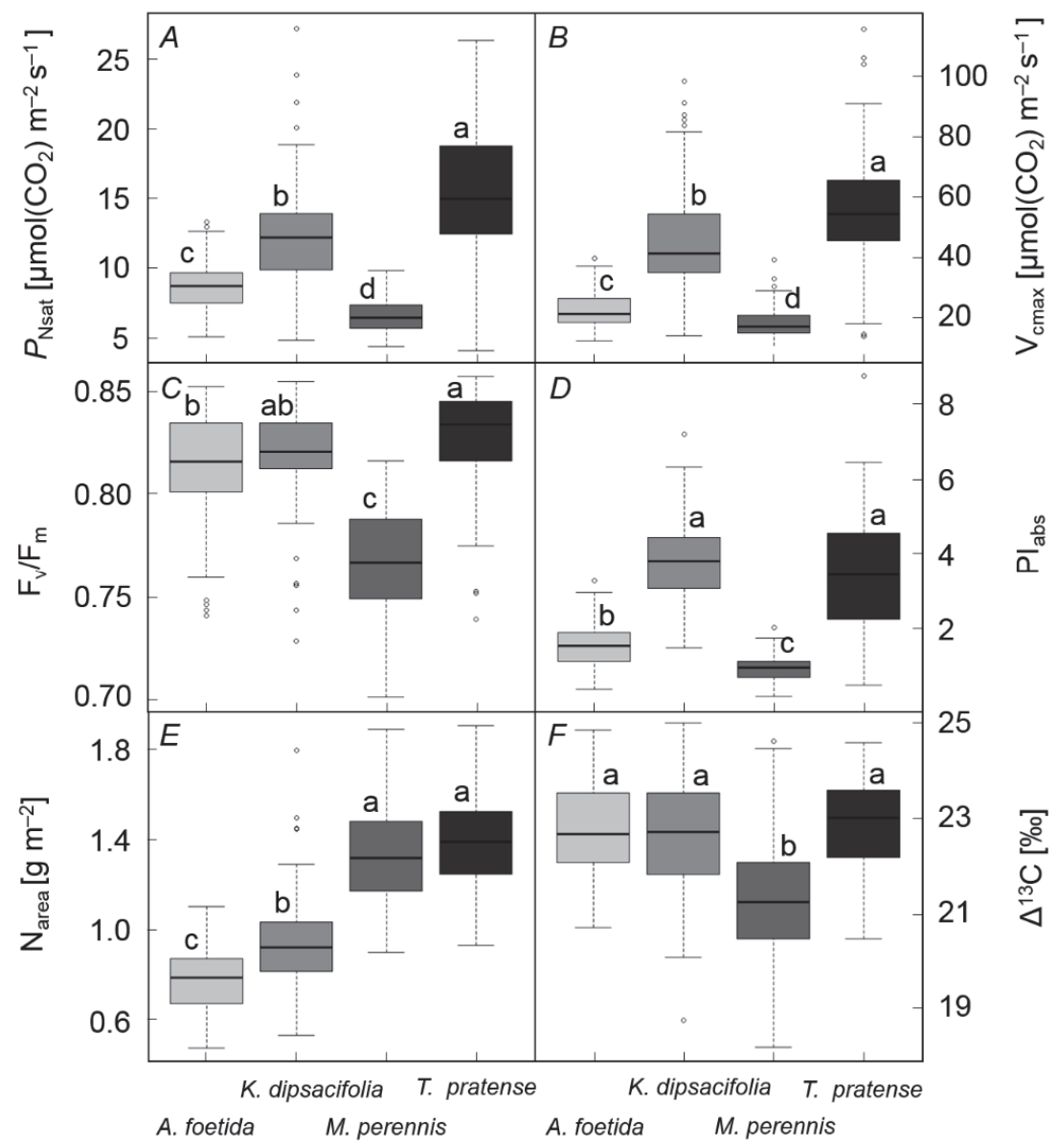

Fig. 1. Boxplots of the parameters displayed per species $A$ - net photosynthetic rate at saturating irradiance and ambient atmospheric $\mathrm{CO}_{2}$ concentrations $\left(P_{\text {Nsat }}\right), B$ - maximum carboxylation rate $\left(\mathrm{V}_{\mathrm{cmax}}\right), C-$ maximum quantum yield of PSII $\left(\mathrm{F}_{\mathrm{v}} / \mathrm{F}_{\mathrm{m}}\right), D-$ absorption based performance index (PIabs), $E$ - area based leaf nitrogen content $\left(\mathrm{N}_{\text {area }}\right)$, and $F$ - carbon isotope discrimination $\left(\Delta^{13} \mathrm{C}\right)$. Significant differences between species $(p<0.001)$ are indicated by letters.

temperature conditions ( $K$. dipsacifolia and $T$. pratense). $\mathrm{F}_{\mathrm{v}} / \mathrm{F}_{\mathrm{m}}$ was again species-specific $\left(\mathrm{F}_{3,374}=107.0, p<0.001\right)$, but these differences were not as pronounced (Fig. $1 C$ ), as A. foetida did not differ significantly from $K$. dipsacifolia . M. perennis displayed the lowest values. In $\mathrm{PI}_{\mathrm{abs}}$, there were again species-specific differences $\left(\mathrm{F}_{3,374}=186.2\right.$, $p<0.001)$ with spring-flowering species displaying lower values than summer-flowering species, yet there was no difference between $K$. dipsacifolia and $T$. pratense (Fig. 1D). Species also differed in their ecophysiological trait values, yet the effect of seasonality was not so clear. Species differed in $\mathrm{N}_{\text {area }}\left(\mathrm{F}_{3,389}=180.1, p<0.001\right)$ but there was no difference in $\mathrm{N}_{\text {area }}$ values between $M$. perennis and $T$. pratense (Fig. $1 E$ ). There were also species-specific differences in $\Delta^{13} \mathrm{C}\left(\mathrm{F}_{3,390}=43.0, p<0.001\right)$, yet $A$. foetida $K$. dipsacifolia and $T$. pratense showed no differences in $\Delta^{13} \mathrm{C}$ values, while $M$. perennis displayed lower values than the other species (Fig. $1 F$ ).

The relation of $\boldsymbol{P}_{\mathrm{s} s a t}$ and $\mathbf{V}_{\mathbf{c m a x}}$ to $\mathbf{F}_{\mathbf{v}} / \mathbf{F}_{\mathbf{m}}$ : We found no significant association between $P_{\text {Nsat }}$ and $\mathrm{F}_{\mathrm{v}} / \mathrm{F}_{\mathrm{m}} ; P_{\text {Nsat }}$ only differed between species $\left(R^{2}{ }_{\text {marginal }}=0.51, R^{2}\right.$ conditional $=0.60$;
Figs. $1 A, 2 A$; Table $1 \mathrm{~S}$ - supplement available online). $\mathrm{V}_{\mathrm{cmax}}$ was significantly related to $\mathrm{F}_{\mathrm{v}} / \mathrm{F}_{\mathrm{m}}\left(R_{\text {marginal }}^{2}=0.56\right.$, $R_{\text {conditional }}^{2}=0.68 ;$ Figs. $2 B ; 1 \mathrm{~S}-$ supplement available online) yet this relationship was highly species-specific. Unexpectedly, the direction of the relationship between $\mathrm{F}_{\mathrm{v}} / \mathrm{F}_{\mathrm{m}}$ and $\mathrm{V}_{\mathrm{cmax}}$ differed between species; M. perennis showed a positive relation, while $A$. foetida, K. dipsacifolia, and $T$. pratense displayed a negative relation (Fig. $2 B$ ).

The relation of $\boldsymbol{P}_{\mathrm{Nsat}}$ and $\mathbf{V}_{\mathrm{cmax}}$ to $\mathbf{P I}_{\mathrm{abs}}$ : As shown in Fig. $2 C, P_{\text {Nsat }}$ was positively related to $\mathrm{PI}_{\mathrm{abs}}$ for all species $\left(R_{\text {marginal }}^{2}=0.53, R_{\text {conditional }}^{2}=0.65 ;\right.$ Table $\left.1 \mathrm{~S}\right)$. Species differed in their intercept, but not in the slopes.

$\mathrm{V}_{\text {cmax }}$ was significantly related to $\mathrm{PI}_{\mathrm{abs}}\left(R^{2}{ }_{\text {marginal }}=0.53\right.$, $R_{\text {conditional }}^{2}=0.69$; Table $\left.1 \mathrm{~S}\right)$ and again there was a speciesspecific difference in the intercept, but not in the slope of the reaction (Fig. 2D).

The relationship of photosynthesis measurements to $\mathbf{N}_{\text {area }}$ and $\boldsymbol{\Delta}^{\mathbf{1 3}} \mathbf{C}$ : $\mathrm{N}_{\text {area }}$ as proxy for Rubisco content was positively related to $P_{\text {Nsat }}\left(R_{\text {marginal }}^{2}=0.63, R_{\text {conditional }}^{2}=\right.$ $0.69), \mathrm{V}_{\mathrm{cmax}}\left(R_{\text {marginal }}^{2}=0.65, R_{\text {conditional }}=0.73\right)$, and $\mathrm{PI}_{\mathrm{abs}}$ 


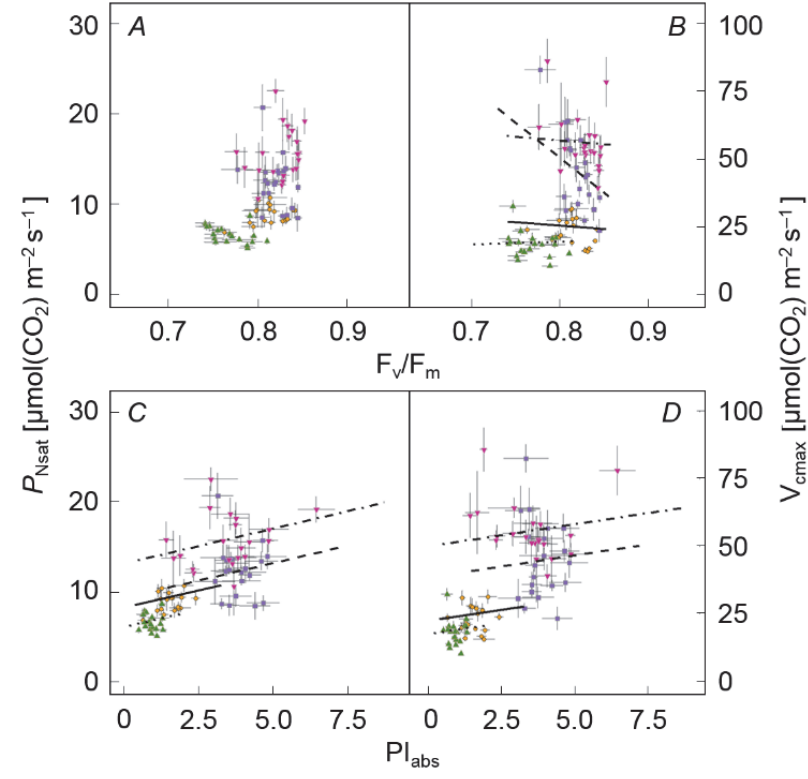

Fig. 2. Relationship between maximum quantum yield of PSII $\left(\mathrm{F}_{\mathrm{v}} / \mathrm{F}_{\mathrm{m}}\right)$ and $A$ - net photosynthetic rate at saturating irradiance and ambient atmospheric $\mathrm{CO}_{2}$ concentrations $\left(P_{\text {Nsat }}\right)$ and $B-$ maximum carboxylation rate $\left(\mathrm{V}_{\mathrm{cmax}}\right)$ as well as the relationship of absorption based performance index ( $\left.\mathrm{PI}_{\mathrm{abs}}\right)$ and $C-P_{\text {Nsat }}$ as well as $D-\mathrm{V}_{\text {cmax. }}$. Indicated are the mean values per species, gradient, and elevational band. Yellow circles and solid lines display $A$. foetida, purple squares and dashed lines $K$. dipsacifolia, green upwards pointing triangles, and dotted lines represent $M$. perennis and magenta downwards pointing triangles and dotteddashed lines T. pratense. Error bars display the standard error of the measurements per elevational band and gradient.

$\left(R_{\text {marginal }}=0.64, R_{\text {conditional }}=0.71\right)$, yet it showed no significant relationship to $\mathrm{F}_{\mathrm{v}} / \mathrm{F}_{\mathrm{m}}\left(R_{\text {marginal }}^{2}=0.46, R_{\text {conditional }}^{2}=\right.$ 0.55 ; Fig. $3 A-D$, Table $2 \mathrm{~S}-$ supplement available online). For $P_{\text {Nsat }}$, there was a positive influence of $\mathrm{N}_{\text {area }}$ and a significant interaction between $\mathrm{N}_{\text {area }}$ and species, so the species differed in the strength of the relationship (Fig. $3 A$ ). For $\mathrm{V}_{\text {cmax }}$, there was a positive effect of $\mathrm{N}_{\text {area }}$ and again, species differed in their slopes as well as their intercepts (Figs. 3B; $2 \mathrm{~S}$ ). $\mathrm{N}_{\text {area }}$ was significantly related to $\mathrm{PI}_{\mathrm{abs}}$, there was a significant species effect and a significant interaction between species and $\mathrm{N}_{\text {area }}$ (Fig. 3C). In general, the two early flowering species, $A$. foetida and M. perennis, showed shallower slopes for all relationships described here than the two late flowering species (K. dipsacifolia and T. pratense).

$\Delta^{13} \mathrm{C}$ was negatively related to $P_{\text {Nsat }}\left(R_{\text {marginal }}^{2}=0.59\right.$, $\left.R_{\text {conditional }}^{2}=0.64\right), \mathrm{V}_{\text {cmax }}\left(R_{\text {marginal }}^{2}=0.61, R_{\text {conditional }}^{2}=\right.$ $0.70)$, and $\mathrm{PI}_{\mathrm{abs}}\left(R_{\text {marginal }}^{2}=0.60, R_{\text {conditional }}^{2}=0.66\right)$ and there was a positive relationship between $\Delta^{13} \mathrm{C}$ and $\mathrm{F}_{\mathrm{v}} / \mathrm{F}_{\mathrm{m}}$ $\left(R_{\text {marginal }}^{2}=0.49, R_{\text {conditional }}^{2}=0.56 ;\right.$ Fig. $\left.3 E-H ; 2 \mathrm{~S}\right)$. The two early flowering species showed a shallower slope for their relationship between $\Delta^{13} \mathrm{C}$ and $P_{\text {Nsat }}$ as well as $\mathrm{V}_{\text {cmax }}$ whereas there was no species-specific slope (i.e. inter action with species) for the relationship between $\Delta^{13} \mathrm{C}$ and $\mathrm{PI}_{\mathrm{abs}}$. There was a positive relationship between $\Delta^{13} \mathrm{C}$ and

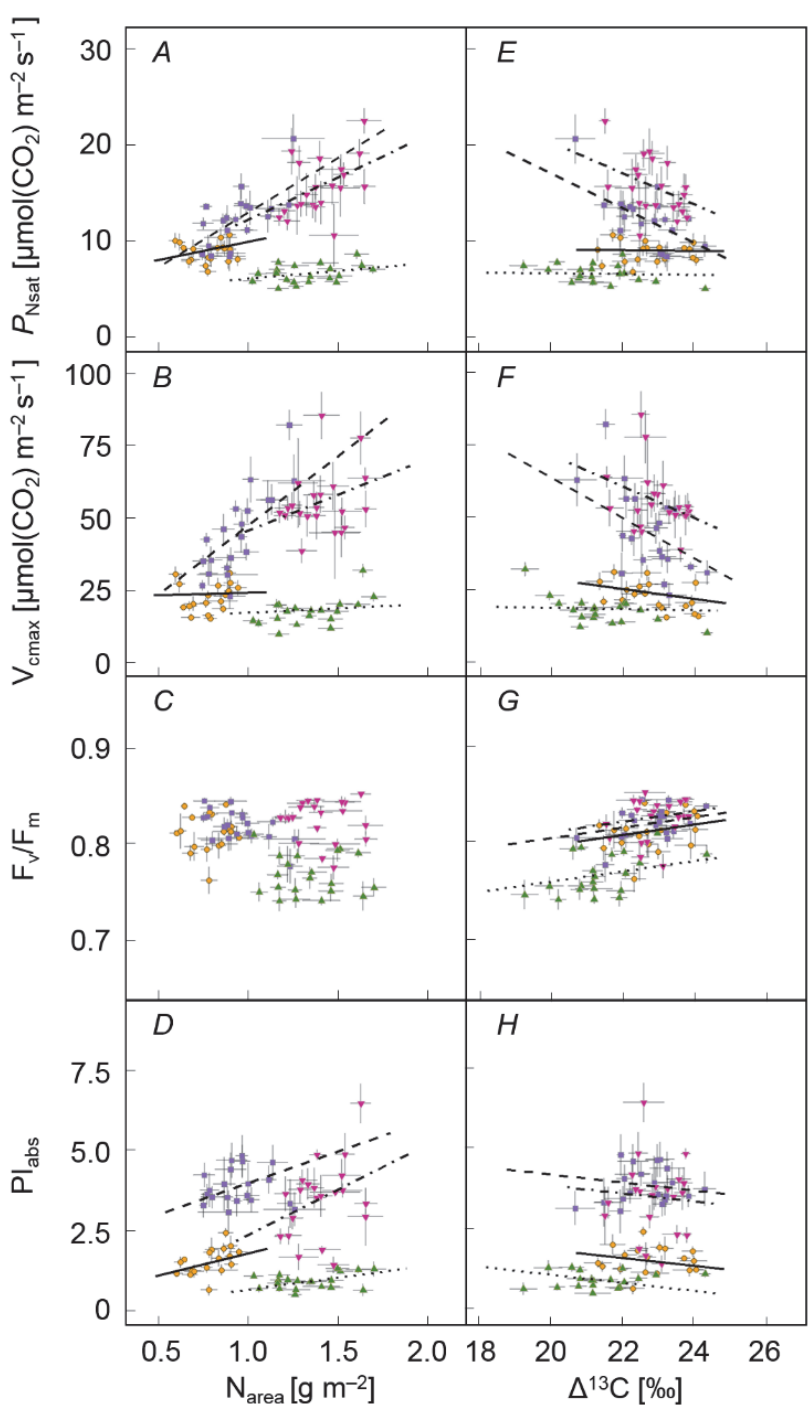

Fig. 3. Relationship between net photosynthetic rate at saturating irradiance and ambient atmospheric $\mathrm{CO}_{2}$ concentrations $\left(P_{\mathrm{Nsat}}\right)$, maximum carboxylation rate $\left(\mathrm{V}_{\mathrm{cmax}}\right)$, maximum quantum yield of PSII $\left(\mathrm{F}_{\mathrm{v}} / \mathrm{F}_{\mathrm{m}}\right)$, and absorption based performance index $\left(\mathrm{PI}_{\mathrm{abs}}\right)$ to area based leaf nitrogen content $\left(\mathrm{N}_{\text {area }}\right.$; left panel, $\left.A-D\right)$ and carbon isotope discrimination $\left(\Delta^{13} \mathrm{C}\right.$; right panel, $\left.E-H\right)$. Indicated are the mean values per species, gradient, and elevational band. Yellow circles and solid lines display A. foetida, purple squares and dashed lines $K$. dipsacifolia, green upwards pointing triangles and dotted lines represent $M$. perennis, and magenta downwards pointing triangles and dotted-dashed lines $T$. pratense. Error bars display the standard error of the measurements per elevational band and gradient.

$\mathrm{F}_{\mathrm{v}} / \mathrm{F}_{\mathrm{m}}$. For $P_{\text {Nsat }}$, there was a negative influence of $\Delta \Delta^{13} \mathrm{C}$ and a significant interaction between $\Delta^{13} \mathrm{C}$ and species as well as a significant effect of species (Fig. $3 E$ ). For $\mathrm{V}_{\text {cmax }}$ there was a negative effect of $\Delta^{13} \mathrm{C}$, a significant species effect and a highly significant interaction between $\Delta^{13} \mathrm{C}$ and species (Fig. $3 F$ ). $\Delta^{13} \mathrm{C}$ was negatively related to $\mathrm{PI}_{a b s}$ with a significant species effect (Fig. $3 G$ ) and it was significantly positively related to $\mathrm{F}_{\mathrm{v}} / \mathrm{F}_{\mathrm{m}}$ with a significant species effect (Fig. $3 H$ ). 


\section{Discussion}

In our study based on field measurements, $\mathrm{F}_{\mathrm{v}} / \mathrm{F}_{\mathrm{m}}$ was a rather poor predictor of assimilation and carboxylation rates, hence we cannot recommend $\mathrm{F}_{\mathrm{v}} / \mathrm{F}_{\mathrm{m}}$ as a proxy for photosynthetic activity in field studies since $F_{v} / F_{m}$ seems to capture different processes. We found a predominantly negative relationship between $\mathrm{F}_{\mathrm{v}} / \mathrm{F}_{\mathrm{m}}$ and $\mathrm{V}_{\mathrm{cmax}}$ and no relationship between $\mathrm{F}_{\mathrm{v}} / \mathrm{F}_{\mathrm{m}}$ and $P_{\mathrm{Nsat}}$ contradictory to the laboratory measurements by Sharma et al. (2015). Per definition, $F_{\mathrm{v}} / \mathrm{F}_{\mathrm{m}}$ should fit well with the quantum yield at low to intermediate light conditions (Ögren and Sjöström 1990) as it measures the quantum yield of PSII. Especially in $\mathrm{C}_{4}$ plants, with low photorespiration, the link between the quantum yield of PSII and the quantum yield of $\mathrm{CO}_{2}$ fixation is very tight (Genty et al. 1989). But also in $\mathrm{C}_{3}$ plants, such as the four species of our case study, these parameters should scale since Ögren and Sjöström (1990) reported a relationship between low $\mathrm{F}_{\mathrm{v}} / \mathrm{F}_{\mathrm{m}}$ and low quantum yield of the photosynthesis in Salix species. The discrepancies in between PSII electron transport and $\mathrm{CO}_{2}$ fixation observed may be caused by changes in relative rates of $\mathrm{CO}_{2}$ fixations and processes, which are competing for electrons. Amongst these are photorespiration, when Rubisco is acting as oxygenase instead of carboxylase, electrons used in nitrogen metabolism, the Mehler reaction, where electrons originating from PSI reduce $\mathrm{O}_{2}$ to a superoxide anion, which is disposed via $\mathrm{H}_{2} \mathrm{O}_{2}$ and transformed into water (photosynthetic water-water cycle), and the oxygen photoreduction within the thylakoids, which is important mainly to dissipate excess excitation energy (Maxwell and Johnson 2000, Heber 2002, Kalaji et al. 2016, 2017a). Photosynthesis was measured at different temperatures for early and late flowering species and no control of temperature $\mathrm{Chl} a$ fluorescence was possible due to technical limitations (which explains different levels of $P_{\text {Nsat }}$; Fig. $1 A$ ), yet temperatures were kept constant within species, so relationships to other parameters were not affected. Differences between gas exchange and Chl $a$ flourescence measurements can also be explained with the fact that only the uppermost layers of plant tissue are engaged in Chl $a$ fluorescence, so when measuring the adaxial side only, we merely probed the chloroplasts of the palisade parenchyma cells (Vogelmann and Evans 2002, Lichtenthaler et al. 2005). Differently, gas exchange engulfs both sides of the leaves. However, due to the anatomy and optical properties of dorsi-ventral leaves, the adaxial and abaxial side of the leaf differ substantially (Schreiber et al. 1977, Vogelmann 1993), thus measuring both leaf sides and calculating a mean proves to be difficult. The species-specific differences could hence arise from the fact that $M$. perennis is functionally hypostomatic, whereas the other species selected in this study are amphistomatic (Bucher et al. 2017). Hypostomatic species typically display lower photosynthetic capacities than amphistomatic species (Parkhurst 1994) which can be also seen in our study (Fig. 1A). The difference in stomatal patterning and consequently leaf anatomy might also affect the quantum yield of PSII and thus the very low level of $\mathrm{F}_{\mathrm{v}} / \mathrm{F}_{\mathrm{m}}$ in $M$. perennis and the difference in the direction of the relationship between $\mathrm{F}_{\mathrm{v}} / \mathrm{F}_{\mathrm{m}}$ and $\mathrm{V}_{\mathrm{cmax}}$ as compared to the other species (Fig. 1C). The relatively low $\mathrm{F}_{\mathrm{v}} / \mathrm{F}_{\mathrm{m}}$ in $M$. perennis could be also due to the fact, that this species is more affected by low temperatures of the night before the measurements (Fig. 3S - supplement available online) which could be due to its erect growth form contrasting the rosette of A. foetida (Larcher 1994, Körner 2003).

The performance index $\mathrm{PI}_{\mathrm{abs}}$ was positively related to $P_{\text {Nsat }}$ and $\mathrm{V}_{\text {cmax }}$, which indicates its utility as a proxy in large field studies. Even though absolute values in $\mathrm{PI}_{\mathrm{abs}}$ differed between species, the relation was much less species-specific than the relation of $\mathrm{F}_{\mathrm{v}} / \mathrm{F}_{\mathrm{m}}$ to $P_{\text {Nsat }}$ or $\mathrm{V}_{\mathrm{cmax}}$ since no species-specific slope in its relationship to $P_{\text {Nsat }}$ and $\mathrm{V}_{\text {cmax }}$ could be observed. Our results confirmed the expected positive relationship between $P_{\text {Nsat }}$ and $\mathrm{V}_{\mathrm{cmax}}$ and $\mathrm{PI}_{\text {abs }}$ to $\mathrm{N}_{\text {area }}$, which is a proxy for Rubisco content (Evans 1989), but not between $F_{v} / F_{m}$ and $N_{\text {area }}$. It is interesting to see that these relationships were much weaker in the spring, thus in early flowering species, than in the late flowering species. This is especially the case for M. perennis, which is a more shade loving species (Ellenberg's indicator value for light of 2) than the other species [A. foetida: 4, K. dipsacifolia: 5, and T. pratense: 7 (Ellenberg 1974, Ellenberg et al. 1991)]. Shade leaves and shade species were previously shown to display lower photosynthetic rates in addition to many other differences in their leaf anatomy (Wild et al. 1975, Boardman 1977, Larcher 1994) and partition relatively more nitrogen into the thylakoids, although this is associated with lower photosynthetic capacity per unit nitrogen (Evans 1989). However, our analysis showed that M. perennis has similar $\mathrm{N}_{\text {area }}$ as $T$. pratense, which is a nitrogen fixator (see Fig. 1E). An experimental study using dilute solutions of $\mathrm{Chl}$ molecules indicated that fluorescence intensity is related to the quantum yield of photosynthesis and Chl concentration (Lakowicz 2006), whereas Dinç et al. (2012) showed that $F_{m}$ as well as $F_{0}$ are not related to Chl content in leaves and only changes in antenna size did have an effect on $\mathrm{F}_{\mathrm{m}}$. The different strength in the relationship could be linked to the species habitat preferences, which in the case of $M$. perennis explains the lower photosynthetic rates (Boardman 1977). This is also reflected in lower $\mathrm{PI}_{\mathrm{abs}}$ and also lower $F_{v} / F_{m}$ and the weaker relationship to $N_{\text {area. }}$.

We confirmed our hypothesis and found a negative relationship between $\Delta^{13} \mathrm{C}$ and $P_{\mathrm{Nsat}}, \mathrm{V}_{\mathrm{cmax}}$, and $\mathrm{PI}_{\text {abs. }}$. Since $\Delta^{13} \mathrm{C}$ is lower in case of a strong $\mathrm{CO}_{2}$ gradient resulting either from closed stomata or high $\mathrm{CO}_{2}$ demand via higher photosynthetic rates (Farquhar et al. 1989), the fact that we observed the same pattern in $\mathrm{PI}_{\mathrm{abs}}$ underlines its strong correlation with the parameters resulting from gasexchange measurements. In addition to that, hypostomaty, 
as in the case of $M$. perennis, leads to a longer diffusion path length between stomata and the sites of carboxylation, which was found by Parkhurst (1994), and it might strengthen this $\mathrm{CO}_{2}$ gradient and thus lead to the low values in $\Delta^{13} \mathrm{C}$ for this species (Fig. $1 F$ ). At the same time, $\mathrm{F}_{\mathrm{v}} / \mathrm{F}_{\mathrm{m}}$ decreased with lower $\Delta^{13} \mathrm{C}$ which might capture the "stress" component of this parameter. Stress could be induced via closed stomata which results in an increased photorespiration activity at the cost of assimilation and temperature stress due to the lack of evaporation which could then lead to a decrease in $\mathrm{F}_{\mathrm{v}} / \mathrm{F}_{\mathrm{m}}$ (Medrano et al. 2002, Kalaji et al. 2017b). However, previous research found that $\mathrm{F}_{\mathrm{v}} / \mathrm{F}_{\mathrm{m}}$ is insensitive towards stomatal changes and other effects occurring under moderate drought stress (Suresh et al. 2012, Kalaji et al. 2017b). We only found a positive relation of the minimum temperatures during the night before the measurements and $\mathrm{F}_{\mathrm{v}} / \mathrm{F}_{\mathrm{m}}$ and not to actual leaf temperatures (Fig. 3S), but this field needs further elaboration.

Photosynthesis and electron transport rate is known to vary intraspecifically between seasons, with higher photosynthetic rates in the summer and lower efficiencies in the winter or during senescence and spring (Jenkins and Woolhouse 1981, Troeng and Linder 1982, Larcher 1994, Öquist and Huner 2003, Adams et al. 2004, Neuner and Pramsohler 2006, Holland et al. 2014). Thus, a seasonal effect cannot be ruled out also given the fact that gas-

\section{References}

Adams III W.W., Zarter C.R., Ebbert V. et al.: Photoprotective strategies of overwintering evergreens. - BioScience 54: 4149, 2004.

Bartoń K.: Multi-Model Inference. R Package Version 1.15. 6 2016.

Bates D., Mächler M., Bolker B. et al.: Fitting linear mixedeffects models using Ime4. - J. Stat. Softw. 67: 1-48, 2015.

Bernacchi C., Singsaas E., Pimentel C. et al.: Improved temperature response functions for models of Rubisco-limited photosynthesis. - Plant Cell Environ. 24: 253-259, 2001.

Boardman N.K.: Comparative photosynthesis of sun and shade plants. - Annu. Rev. Plant Physiol. 28: 355-377, 1977.

Bond B.J., Farnsworth B.T., Coulombe R.A. et al:: Foliage physiology and biochemistry in response to light gradients in conifers with varying shade tolerance. - Oecologia 120: 183192, 1999.

Bucher S.F., Auerswald K., Grün-Wenzel C. et al:: Stomatal traits relate to habitat preferences of herbaceous species in a temperate climate. - Flora 229: 107-115, 2017.

Bucher S.F., Auerswald K., Tautenhahn S. et al.: Inter- and intraspecific variation in stomatal pore area index along elevational gradients and its relation to leaf functional traits. - Plant Ecol. 217: 229-240, 2016.

Clark A.J., Landolt W., Bucher J. et al.: Beech (Fagus sylvatica) response to ozone exposure assessed with a chlorophyll a fluorescence performance index. - Environ. Pollut. 109: 501507, 2000.

Collatz G.J., Ball J.T., Grivet C. et al:: Physiological and environmental regulation of stomatal conductance, photosynthesis and transpiration: a model that includes a laminar exchange measurements were conducted at different temperatures as outlined above. In our study, all parameters were highly species-specific (Fig. 1) and higher in the summer than in the spring. Nevertheless, the differences of species within the season should be more elaborated.

Our findings give important implications for terrestrial biosphere models (TBMs) since they rely, among others, on correct estimates of $\mathrm{V}_{\mathrm{cmax}}$ (Zaehle et al. 2005) and the relationship between leaf nitrogen content and its scaling with both, photosynthetic rates and $\mathrm{V}_{\text {cmax }}$ (Kattge et al. 2009). Thus, Chl $a$ fluorescence might be a fast way to estimate this parameter, when aiming to include aspects of intraspecific variability since we could demonstrate its relationship with traits such as $\mathrm{N}_{\text {area }}$ and $\Delta^{13} \mathrm{C}$. Further studies need to test whether these correlations also hold on the level of species (interspecific scale). However, the fact that $\mathrm{PI}_{\mathrm{abs}}$ is positively related to $P_{\text {Nsat }}$ and $\mathrm{V}_{\mathrm{cmax}}$ and also shows the same patterns, when relating it to indirect measurements of plant performance via plant traits, is an important finding for future measurements and supports our hypothesis that $\mathrm{Chl} a$ fluorescence techniques might serve as a proxy for the cost and labour intensive gasexchange measurements. For field ecologists depending on extensive measurement campaigns, we recommend to use $\mathrm{PI}_{\mathrm{abs}}$ for a characterisation of photosynthetic rates, but to be careful in relying on $\mathrm{F}_{\mathrm{v}} / \mathrm{F}_{\mathrm{m}}$.

boundary layer. - Agr. Forest Meteorol. 54: 107-136, 1991.

Crawley M.J.: The R Book. Pp. 681-713. John Wiley \& Sons, Chichester 2012.

de Bello F., Lavorel S., Díaz S. et al.: Towards an assessment of multiple ecosystem processes and services via functional traits. - Biodivers. Conserv. 19: 2873-2893, 2010.

De Kauwe M.G., Lin Y.S., Wright I.J. et al.: A test of the 'onepoint method'for estimating maximum carboxylation capacity from field-measured, light-saturated photosynthesis. - New Phytol. 210: 1130-1144, 2015.

Demmig-Adams B., Adams III W.W., Winter K. et al.: Photochemical efficiency of photosystem II, photon yield of $\mathrm{O}_{2}$ evolution, photosynthetic capacity, and carotenoid composition during the midday depression of net $\mathrm{CO}_{2}$ uptake in Arbutus unedo growing in Portugal. - Planta 177: 377-387, 1989.

Desotgiu R., Pollastrini M., Cascio C. et al.: Responses to ozone on Populus "Oxford" clone in an open top chamber experiment assessed before sunrise and in full sunlight. - Photosynthetica 51: 267-280, 2013.

Dias M., Brüggemann W.: Limitations of photosynthesis in Phaseolus vulgaris under drought stress: gas exchange, chlorophyll fluorescence and Calvin cycle enzymes. Photosynthetica 48: 96-102, 2010.

Dinç E., Ceppi M.G., Tóth S.Z. et al.: The chl $a$ fluorescence intensity is remarkably insensitive to changes in the chlorophyll content of the leaf as long as the chl $a / b$ ratio remains unaffected. - BBA-Bioenergetics 1817: 770-779, 2012.

Ellenberg H.: Indicator values of vascular plants in central Europe. - Scripta Geobot. 9: 97, 1974. 
Ellenberg H., Weber H., Dul R. et al.: [Indicator values of Centraleuropean plant species.] - Scripta Geobot. 18: 248, 1991. [In German]

Evans J.R.: Photosynthesis and nitrogen relationships in leaves of $\mathrm{C}_{3}$ plants. - Oecologia 78: 9-19, 1989.

Farquhar G.D., Ehleringer J.R., Hubick K.T.: Carbon isotope discrimination and photosynthesis. - Annu. Rev. Plant Phys. 40: 503-537, 1989.

Farquhar G.D., von Caemmerer S., Berry J.: A biochemical model of photosynthetic $\mathrm{CO}_{2}$ assimilation in leaves of $\mathrm{C}_{3}$ species. - Planta 149: 78-90, 1980.

Genty B., Briantais J.-M., Baker N.R.: The relationship between the quantum yield of photosynthetic electron transport and quenching of chlorophyll fluorescence. - Biochim. Biophys. Acta 990: 87-92, 1989.

Giorio P.: Black leaf-clips increased minimum fluorescence emission in clipped leaves exposed to high solar radiation during dark adaptation. - Photosynthetica 49: 371-379, 2011.

Grassi G., Vicinelli E., Ponti F. et al.: Seasonal and interannual variability of photosynthetic capacity in relation to leaf nitrogen in a deciduous forest plantation in northern Italy. - Tree Physiol. 25: 349-360, 2005.

Heber U.: Irrungen, Wirrungen? The Mehler reaction in relation to cyclic electron transport in $\mathrm{C}_{3}$ plants. - Photosynth. Res. 73: 223-231, 2002.

Holland V., Koller S., Brüggemann W.: Insight into the photosynthetic apparatus in evergreen and deciduous European oaks during autumn senescence using OJIP fluorescence transient analysis. - Plant Biol. 16: 801-808, 2014.

Jenkins G., Woolhouse H.: Photosynthetic electron transport during senescence of the Primary leaves of Phaseolus vulgaris L.: I. Non-cyclic electron transport. - J. Exp. Bot. 32: 467-478, 1981.

Kalaji M.H., Goltsev V.N., Żuk-Gołaszewska K. et al.: Chlorophyll fluorescence: understanding crop performance. - Basics and Applications. Pp. 236. CRC Press Taylor \& Francis Group, Boca Raton 2017a.

Kalaji H.M., Schansker G., Brestic M. et al.: Frequently asked questions about chlorophyll fluorescence, the sequel. Photosynth. Res. 132: 13-66, $2017 \mathrm{~b}$.

Kalaji H.M., Schansker G., Ladle R.J. et al.: Frequently asked questions about in vivo chlorophyll fluorescence: practical issues. - Photosynth. Res. 122: 121-158, 2014.

Kattge J., Knorr W., Raddatz T. et al.: Quantifying photosynthetic capacity and its relationship to leaf nitrogen content for global-scale terrestrial biosphere models. - Glob. Change Biol. 15: 976-991, 2009.

Kautsky H., Franck U.: [Chlorophyll fluorescence and carbonic acid assimilation.] - Biochem. Z. 315: 139-232, 1943. [In German]

Kitajima M., Butler W.: Quenching of chlorophyll fluorescence and primary photochemistry in chloroplasts by dibromothymoquinone. - BBA-Bioenergetics 376: 105-115, 1975.

Körner C.: Alpine Plant Life: Functional Plant Ecology of High Mountain Ecosystems; with 47 Tables. Pp. 349. Springer Science \& Business Media, Berlin - Heidelberg - New York 2003.

Küppers M., Swan A., Tompkins D. et al.: A field portable system for the measurement of gas exchange of leaves under natural and controlled conditions: examples with field-grown Eucalyptus pauciflora Sieb. ex Spreng. ssp. pauciflora, E. behriana F. Muell. and Pinus radiata R. Don. - Plant Cell Environ. 10: 425-435, 1987.
Kuznetsova A., Brockhoff P.B., Christensen R.H.B.: ImerTest: Tests in Linear Mixed Effects Models. R Package Version 2.0$29,2015$.

Lakowicz J.R., Masters B.R.: Principles of Fluorescence Spectroscopy. Pp. 954. Springer Science \& Business Media, Berlin - Heidelberg - New York 2006.

Larcher W.: [Ecophysiology of Plants.] Pp. 408. Eugen Ulmer Verlag, Stuttgart 1994. [In German]

Lazár D.: The polyphasic chlorophyll $a$ fluorescence rise measured under high intensity of exciting light. - Funct. Plant Biol. 33: 9-30, 2006.

Lichtenthaler H., Buschmann C., Knapp M.: How to correctly determine the different chlorophyll fluorescence parameters and the chlorophyll fluorescence decrease ratio RFd of leaves with the PAM fluorometer. - Photosynthetica 43: 379-393, 2005.

Lichtenthaler H., Buschmann C., Rinderle U. et al.: Application of chlorophyll fluorescence in ecophysiology. - Radiat. Environ. Bioph. 25: 297-308, 1986.

Maxwell K., Johnson G. N.: Chlorophyll fluorescence - a practical guide. - J. Exp. Bot. 51: 659-668, 2000.

Medrano H., Escalona J. M., Bota J. et al:: Regulation of photosynthesis of $\mathrm{C}_{3}$ plants in response to progressive drought: stomatal conductance as a reference parameter. - Ann. Bot.London 89: 895-905, 2002.

Nakagawa S., Schielzeth H.: A general and simple method for obtaining $\mathrm{R}^{2}$ from generalized linear mixed-effects models. Methods Ecol. Evol. 4: 133-142, 2013.

Neuner G., Ambach D., Aichner K.: Impact of snow cover on photoinhibition and winter desiccation in evergreen Rhododendron ferrugineum leaves during subalpine winter. - Tree Physiol. 19: 725-732, 1999.

Neuner G., Pramsohler M.: Freezing and high temperature thresholds of photosystem 2 compared to ice nucleation, frost and heat damage in evergreen subalpine plants. - Physiol. Plantarum 126: 196-204, 2006.

Ögren E., Sjöström M.: Estimation of the effect of photoinhibition on the carbon gain in leaves of a willow canopy. Planta 181: 560-567, 1990.

Öquist G., Huner N.P.: Photosynthesis of overwintering evergreen plants. - Annu. Rev. Plant Biol. 54: 329-355, 2003.

Parkhurst D.F.: Diffusion of $\mathrm{CO}_{2}$ and other gases inside leaves. New Phytol. 126: 449-479, 1994.

Pérez-Harguindeguy N., Díaz S., Garnier E. et al.: New handbook for standardised measurement of plant functional traits worldwide. - Aust. J. Bot. 61: 167-234, 2013.

Pflug E., Brüggemann W.: Frost-acclimation of photosynthesis in overwintering Mediterranean holm oak, grown in Central Europe. - Int. J. Plant Biol. 3: e1, 2012.

R Development Core Team.: R: A language and environment for statistical computing. R Foundation for Statistical Computing, Vienna 2016

Rogers A., Humphries S.W.: A mechanistic evaluation of photosynthetic acclimation at elevated $\mathrm{CO}_{2}$. - Glob. Change Biol. 6: 1005-1011, 2000.

Römermann, C., S.F. Bucher, Hahn M., Bernhardt-Römermann M.: Plant functional traits - fixed facts or variable depending on the season? - Folia Geobot. 51: 143-159, 2016.

Schreiber U., Bilger W., Neubauer C.: Chlorophyll fluorescence as a nonintrusive indicator for rapid assessment of in vivo photosynthesis. - In: Schulze E.D., Caldwell M.M. (ed.): Ecophysiology of Photosynthesis. Pp. 49-70. Springer-Verlag, Berlin - Heidelberg - New York 1995. 
Schreiber U., Fink R., Vidaver W.: Fluorescence induction in whole leaves: differentiation between the two leaf sides and adaptation to different light regimes. - Planta 133: 121-129, 1977.

Sharma D.K., Andersen S.B., Ottosen C.O. et al.: Wheat cultivars selected for high $F_{v} / F_{m}$ under heat stress maintain high photosynthesis, total chlorophyll, stomatal conductance, transpiration and dry matter. - Physiol. Plantarum 153: 284298, 2015.

Strasser R.J., Srivastava A., Tsimilli-Michael M.: Screening the vitality and photosynthetic activity of plants by fluorescence transient. - In: Behl R.K., Punia M.S., Lather B.P.S. (ed.): Crop Improvement for Food Security. Pp. 72-115. SSARM, Hisar 1999.

Strasser R. J., Srivastava A., Tsimilli-Michael M.: The fluorescence transient as a tool to characterize and screen photosynthetic samples. - In: Yunus M., Pathre U., Mohanty P. (ed.): Probing Photosynthesis: Mechanisms, Regulation and Adaptation. Pp. 445-483. Taylor \& Francis, Bristol 2000.

Strasser R. J., Srivastava A., Govindjee: Polyphasic chlorophyll $a$ fluorescence transient in plants and cyanobacteria. Photochem. Photobiol. 61: 32-42, 1995.

Suresh K., Nagamani C., Kantha D.L., Kumar M.K.: Changes in photosynthetic activity in five common hybrids of oil palm (Elaeis guineensis Jacq.) seedlings under water deficit. Photosynthetica 50: 549-556, 2012.

Sušila P., Lazár D., Ilík P. et al.: The gradient of exciting radiation within a sample affects the relative height of steps in the fast chlorophyll $a$ fluorescence rise. - Photosynthetica 42: 161-172, 2004

Troeng E., Linder S.: Gas exchange in a 20-year-old stand of Scots pine. - Physiol. Plantarum 54: 7-14, 1982.
Tyystjärvi E., Koski A., Keränen M. et al.: The Kautsky curve is a built-in barcode. - Biophys. J. 77: 1159-1167, 1999.

Violle C., Navas M.L., Vile D. et al.: Let the concept of trait be functional! - Oikos 116: 882-892, 2007.

Vogelmann T.C.: Plant tissue optics. - Annu. Rev. Plant Biol. 44: 231-251, 1993.

Vogelmann T.C., Evans J.: Profiles of light absorption and chlorophyll within spinach leaves from chlorophyll fluorescence. - Plant Cell Environ. 25: 1313-1323, 2002.

von Caemmerer S., Farquhar G.: Some relationships between the biochemistry of photosynthesis and the gas exchange of leaves. - Planta 153: 376-387, 1981.

Wickham H.: ggplot2 - Elegant Graphics for Data Analysis. Pp. 224. Springer Science \& Business Media, Berlin - Heidelberg - New York 2009.

Wild A., Rühle W., Grahl H.: The effect of light intensity during growth of Sinapis alba on the electron-transport and the noncyclic photophosphorylation. - In: Marcelle R. (ed.): Environmental and Biological Control of Photosynthesis. Pp. 115-121. Springer-Verlag, Berlin - Heidelberg - New York 1975.

Wilson K.B., Baldocchi D.D., Hanson P.J.: Spatial and seasonal variability of photosynthetic parameters and their relationship to leaf nitrogen in a deciduous forest. - Tree Physiol. 20: 565$578,2000$.

Zaehle S., Sitch S., Smith B. et al.: Effects of parameter uncertainties on the modeling of terrestrial biosphere dynamics. - Global Biogeochem. Cy. 19: GB3020, 2005.

Živčák M., Brestič M., Olšovská K. et al.: Performance index as a sensitive indicator of water stress in Triticum aestivum L. Plant Soil Environ. 54: 133-139, 2008. 